\title{
Characteristics of Cookies Supplemented with Oleaster (Elaeagnus angustifolia L.) Flour. I Physicochemical, Sensorial and Textural Properties
}

\author{
Yasemin Sahan ${ }^{1}$, Ayse Neslihan Dundar ${ }^{2}$, Emine Aydin ${ }^{3}$, Asli Kilci ${ }^{1}$, Dilek Dulger ${ }^{4}$, F. Betul Kaplan ${ }^{5}$, \\ Duygu Gocmen ${ }^{1} \&$ Guler Celik ${ }^{6}$ \\ ${ }^{1}$ Uludag Univ., Faculty of Agric., Dep. of Food Eng., Bursa, Turkey \\ ${ }^{2}$ Uludag Univ., Yenisehir Ibrahim Orhan Voc. High School, Bursa, Turkey \\ ${ }^{3}$ Uludag Univ., Keles Voc. High School, Bursa, Turkey \\ ${ }^{4}$ İstanbul Aydin Univ., Anadolu Bil Voc. High School, Istanbul, Turkey \\ ${ }^{5}$ Pamukkale Univ., Faculty of Engineering, Dep. of Food Eng., Denizli, Turkey \\ ${ }^{6}$ The Sci. and Tech. Research Council of Turkey, Bursa Test and Analysis Lab, Bursa, Turkey \\ Correspondence: Yasemin Sahan, Uludag Univ., Faculty of Agric., Dep. of Food Eng., Bursa, Turkey. E-mail: \\ yasemins@uludag.edu.tr
}

Received: November 6, 2012 Accepted: November 20, 2012 Online Published: January 15, 2013

doi: $10.5539 /$ jas.v5n2p160

URL: http://dx.doi.org/10.5539/jas.v5n2p160

\begin{abstract}
Oleaster flours (OFs) were produced from two different genotypes (G1 and G2) by two different methods (oleaster mesocarp flour: OMF and oleaster mesocarp flour with pericarp: OMFP). In this study, OFs were used to replace wheat flour in the cookie formulation (control) at the levels of 5,10,15,20 and $25 \%(\mathrm{w} / \mathrm{w})$. OFs supplementation increased total dietary fiber (TDF) contents and decreased caloric contents of cookies compared to the control. Spread ratio (SR) values of cookies with OFs increased. Cookies with OFs were found to be larger in diameter than control cookies. Increasing of OMF and OMFP levels in the cookies led to darker appearance of the cookies than the control. In general, hardness tends to increase as the level of OMFs and OMFPs increased in the cookies. According to sensory analysis, overall acceptance of cookies were found the best at control sample. However, panelists liked all cookies with OFs moderately or slightly. Especially, the usage of 5\% for OMFs and OMFPs in cookie formulation gave satisfactory results in terms of acceptability. The present study demonstrated that considerable nutritive and functional improvement could be attained by the addition of OFs to cookie formulation.
\end{abstract}

Keywords: oleaster, oleaster flour, cookie

\section{Introduction}

Oleaster (Elaeagnus angustifolia, Russian olive) belongs to Elaeagnus L. genus and Elaeagnaceae family. Elaeagnus angustifolia $\mathrm{L}$. is a shrub or tree with a height of up to $7 \mathrm{~m}$ and a capacity to grow under a wide range of environmental conditions (Klich, 2000). This species shows a broad geographical range, occurring widely in Asia and Europe, particularly in Turkey, Caucasia and Central Asia (Aksoy \& Sahin, 1999). It is widely cultivated for its edible fruits in Middle and East Anatolia. The fruits are reddish-brown, elliptic, 9-12 mm long and 6-10 $\mathrm{mm}$ wide and they mature in September. It is consumed either freshly or in dried form. The fruits are used as diuretic, tonic, antipyretic, antidiarrheal and as a medication against kidney disorders (inflammatory or to pass kidney stone) in traditional Turkish medicine (Ayaz \& Bertoft, 2001; Gurbuz et al., 2003), against dysentery and diarrhea in Kingdom of Jordan (Lev \& Amar, 2002) and for its anti-inflammatory, antinociceptive and analgesic effects in Iranian folk medicine. Decoction and infusion of its fruits is considered to be a good remedy for fever, jaundice, asthma, tetanus and rheumatoid arthritis (Ahmadiani et al., 2000).

Oleaster flour may be obtained from dried fruits and used as a functional ingredient in the production of bakery products, yoghurt, ice cream, infant food, chocolate, confectionery etc. due to its floury structure, specific taste and functional properties like dietary fibre, mineral content and phenolic compounds etc. Because of the increasing demand for healthy, functional products have been used to improve functionality of foods by 
modifying their nutritive composition. However, the use of oleaster flour as a functional ingredient in cookies have not been investigated. Hence, the aim of this study was to evaluate the physicochemical, sensorial and textural properties of cookies supplemented with various levels and compositions of oleaster flour.

\section{Material and Methods}

\subsection{Materials}

Two different genotypes were used as oleaster fruit samples. These genotypes were supplied from 2 different regions GO1 $\left(40^{\circ} 11^{\prime} 19.60^{\prime \prime} \mathrm{N}-26^{\circ} 06^{\prime} 09.16^{\prime \prime} \mathrm{E}\right)$ and GO2 $\left(39^{\circ} 34^{\prime} 01.48^{\prime \prime} \mathrm{N}-26^{\circ} 51^{\prime} 02.90^{\prime \prime} \mathrm{E}\right)$ of Turkey. The fruits had approximately same maturity (almost reddish) with uniform shape and size and healthy. Mature fruits were harvested and randomly collected. Harvested fruits were dried at $50^{\circ} \mathrm{C}$ for 20 hours in a hot air oven dryer.

\subsection{Preparation of Oleaster Flour (OF)}

Oleaster flours were produced by two different methods. In the first method; the fruit pericarp and seeds of dry samples were removed using a plastic knife, and then the mesocarp was ground in a coffee grinder and sieved through a standard sieve (mesh size 60). The flour samples were stored in an air tight container at $4^{\circ} \mathrm{C}$ until experiment. This product is called "oleaster mesocarp flour" (OMF). In the second method; only seeds of dry samples were removed using a plastic knife, and then the mesocarp and pericarp were ground together in a coffee grinder and sieved through a standard sieve (mesh size 60). Samples were stored in an air tight container at $4^{\circ} \mathrm{C}$ until experiment. This product is called "oleaster mesocarp flour with pericarp" (OMFP). Sample codes are shown in Table 1.

Table 1. Sample codes

\begin{tabular}{ll}
\hline Codes & \multicolumn{1}{c}{ Sample } \\
\hline G1-OMF & Genotype 1, oleaster mesocarp flour \\
G1-OMFP & Genotype 1, oleaster mesocarp flour with pericarp \\
G2-OMF & Genotype 2, oleaster mesocarp flour \\
G2-OMFP & Genotype 2, oleaster mesocarp flour with pericarp \\
\hline
\end{tabular}

\subsection{Analytical Methods}

Moisture, ash, protein and wet gluten contents were determined according to AACCI Approved Methods 44-15.02, 08-01.01, 46-12.01 and 38-10.01, respectively (AACCI, 1999). Oleaster flours (OFs) were analyzed for moisture (Metod No: 925.40), protein (Metod No:950.48) and ash (Metod No: 950.49) (AOAC, 1990). Dietary fiber contents of flours and cookies were also determined according to AACCI Approved Methods 32-05.01 (AACCI, 1999). Fat contents of cookies were also carried out according to AOAC Metod No: 948.22 (AOAC, 1990). The tests were performed at least in triplicate and mean values are reported.

\subsection{Production of Cookies}

Cookies were prepared using the American Association of Cereal Chemists International (AACCI) method 10-54.01 (AACCI, 1999). The dough was formulated in Table 2. All purpose of shortening added into mixing bowl then added dry ingredients on top of shortening. These ingredients mixed for 3 min stir speed (Electrolux Ditomix 5, EU), scraping every minute. High-fructose corn syrup, appropriate amount of water, ammonium bicarbonate, sodium bicarbonate added into $100 \mathrm{ml}$ beaker and swirl to dissolve. Liquid to creamed mass added and mixed $1 \mathrm{~min}$, scraping every $15 \mathrm{sec}$. Finally calculated amount of flour added and mixed $10 \mathrm{sec}$ while tapping side of bowl, scraped dough from mixer and bowl pins; scrape outer edge and bottom of bowl. Dough was divided into two relatively equal portions and made into oblong shape having approximately $5 \mathrm{~cm}$ length. Both portions placed on ungreased baking sheet. Dough was cut with cookie cutter, discarded excess dough, and remove cutter. Oleaster flours (OMFs and OMFPs) were used to replace wheat flour in the formulation at the levels of 5, 10, 15, 20 and 25\% (w/w) (Table 2). Control sample including no oleaster flour was also prepared. Baking was performed in a convection oven (Inoksan FKE 006, TR) at $175^{\circ} \mathrm{C}$ for $10 \mathrm{~min}$. The baked cookies were left to cool for $30 \mathrm{~min}$ and then they were wrapped in aluminum foil and stored for $24 \mathrm{~h}$ at room temperature prior to analyses. The baked cookies were left to be cool, wrapped and allowed to stand at room temperature prior to analyses. Each batch yielded 4 cookies. 
Table 2. Formulation of cookies

\begin{tabular}{lc}
\cline { 2 - 2 } Ingredients $^{1}$ & Proportion (g) \\
\cline { 2 - 3 } Wheat Flour $^{2}$ & 100 \\
Sucrose & 32 \\
Brownulated granulated sucrose & 10 \\
Nonfat dry milk & 1.0 \\
Salt & 1.25 \\
Sodium bicarbonate & 1.0 \\
All-purpose shortening (fat) & 40 \\
High-fructose corn syrup & 1.5 \\
Ammonium bicarbonate & 0.5 \\
Deionized water & Variable \\
\hline
\end{tabular}

${ }^{1}$ Ingredients at $21 \pm 1{ }^{\circ} \mathrm{C},{ }^{2} 13 \%$ moisture basis.

\subsection{Physical Evaluation of Cookie}

The physical parameters of the cookies were evaluated in terms of diameter (D), thickness (T), and spread ratio $(\mathrm{D} / \mathrm{T})$ values. After cooling of the cookies for $30 \mathrm{~min}$, diameter and thickness measurements were taken using a caliper. Spread ratio was calculated from the ratio of diameter and thickness.

\subsection{Colour Analysis}

The colours of the cookies were measured with a Minolta Spectrophotometer CM-3600d (Osaka, Japan). The Colourimeter was calibrated using a standard white plate. The dimension $L *$ means lightness, with 100 for white, 0 for black; $a *$ indicates redness when high positive and greenness when high negative, $b *$ indicates yellowness when high positive and blueness when negative.

\subsection{Texture Analysis}

A texture analyzer (TA-XT PLUS, Stable Microsystems, UK), equipped with a $50 \mathrm{~kg}$ load cell was used for cookie texture evaluation $24 \mathrm{~h}$ after baking. The fracture force test was conducted on the cookies using a 'measure force in compression' test with 3-point bending jig and heavy duty platform (HDP/90). The hardness of the cookies was indicated by the maximum peak force required to break the cookies. The texture analyzer was set to 'return to start' cycle, a pretest speed of $1.0 \mathrm{~mm} \mathrm{~s}^{-1}$, test speed of $3.0 \mathrm{~mm} \mathrm{~s}^{-1}$, post-test speed of $10 \mathrm{~mm} \mathrm{~s}^{-1}$, and a distance of $5.0 \mathrm{~mm}$ and data acquisition rate, $500 \mathrm{pps}$. The trigger type for cookies was set at $50 \mathrm{~g}$. A force/penetration plot was made for every test. Measurements were conducted three times and results are expressed as mean \pm S.D values.

\subsection{Sensory Analysis}

The sensory characteristics of cookies were screened by an untrained consumer panel with 20 panelists. The instructions were given in full to panelists beforehand. The samples were labeled randomly with 3-digit numbers and evaluated under incandescent light in terms of appearance, taste-flavor, mouthfeel and overall acceptability of the cookies. Samples were served to the panelists in random order to guard against any bias. Water at room temperature was used to clear the mouth before the each test sample. A 9-point hedonic scale with 9-like extremely, 8-like very much, 7-like moderately, 6-like slightly, 5-neither like or dislike, 4-dislike slightly, 3-dislike moderately, 2-dislike very much, and 1-dislike extremely was used. Final judgment was obtained by averaging the scores given by all panelists.

\subsection{Statistical Analysis}

Data were analyzed for variance using the one-way analysis of variance (ANOVA) using the program SPSS 20. When significant differences were found $(P<0.05)$, the least significant difference (LSD) test was used to determine the differences among means. Paired t-test was carried out to compare the properties G1OMF-G2OMF,G1OMFP-G2OMFP. 


\section{Results}

\subsection{Chemical Compositions of Wheat Flour and Oleaster Flours}

Chemical compositions of flour samples are presented in Table 3. The commercial soft wheat flour used in this study consisted of $13.99 \%$ moisture, $0.60 \%$ ash, $9.0 \%$ protein, $29 \%$ wet gluten and $1.69 \%$ total dietary fiber (TDF). The protein contents of the OF samples varied between 3.74 and $4.65 \%$. The protein contents of OFs were significantly $(P<0.05)$ lower than that of soft wheat flour. On the contrary, TDF contents of OFs were significantly $(P<0.05)$ higher than that of the soft wheat flour. Thus, oleaster flour is a good source in TDF, it might be important from the nutrition point of view. The TDF contents of OMF samples were significantly $(P<0.05)$ lower than those of OMFP samples. The higher TDF levels observed for OMFP samples are possibly related to pericarp contents.

Table 3. Chemical compositions of wheat flour and oleaster flours ${ }^{\dagger}$

\begin{tabular}{lccccc}
\hline Sample & $\begin{array}{c}\text { Moisture* } \\
(\mathbf{g} / \mathbf{1 0 0} \mathbf{g})\end{array}$ & $\begin{array}{c}\text { Ash* } \\
\mathbf{( g / 1 0 0 ~} \mathbf{~ g})\end{array}$ & $\begin{array}{c}\text { Protein* } \\
\mathbf{( g / 1 0 0 ~ g )}\end{array}$ & $\begin{array}{c}\text { Wet Gluten } \\
(\mathbf{g} / \mathbf{1 0 0} \mathbf{g})\end{array}$ & $\begin{array}{c}\text { Total Dietary } \\
\text { Fiber } \\
(\mathbf{g} / \mathbf{1 0 0} \mathbf{g})\end{array}$ \\
\hline Wheat flour & $13.99 \pm 0.95^{\mathrm{b}}$ & $0.60 \pm 0.07^{\mathrm{c}}$ & $9.00 \pm 0.25^{\mathrm{a}}$ & 29 & $1.69 \pm 0.07^{\mathrm{e}}$ \\
G1-OMF & $18.99 \pm 1.05^{\mathrm{a}}$ & $2.46 \pm 0.22^{\mathrm{a}}$ & $3.74 \pm 0.26^{\mathrm{c}}$ & --- & $23.55 \pm 0.07^{\mathrm{c}}$ \\
G1-OMFP & $18.43 \pm 1.13^{\mathrm{a}}$ & $2.57 \pm 0.17^{\mathrm{a}}$ & $4.49 \pm 0.17^{\mathrm{b}}$ & --- & $30.65 \pm 0.16^{\mathrm{a}}$ \\
G2-OMF & $19.78 \pm 1.11^{\mathrm{a}}$ & $1.87 \pm 0.15^{\mathrm{b}}$ & $4.51 \pm 0.24^{\mathrm{b}}$ & --- & $20.67 \pm 0.21^{\mathrm{d}}$ \\
G2-OMFP & $20.20 \pm 0.96^{\mathrm{a}}$ & $1.87 \pm 0.21^{\mathrm{b}}$ & $4.65 \pm 0.19^{\mathrm{b}}$ & --- & $25.44 \pm 0.44^{\mathrm{b}}$ \\
\hline
\end{tabular}

*Means with different superscripts in columns indicate significant difference $(P<0.05)$.

${ }^{\dagger}$ Data are expressed as means \pm standard deviations.

Table 4. Chemical compositions of cookies*

\begin{tabular}{|c|c|c|c|c|c|c|}
\hline $\begin{array}{l}\text { Sample } \\
\text { code }\end{array}$ & $\begin{array}{l}\text { OF Level } \\
(\%)\end{array}$ & $\begin{array}{c}\text { Dry Matter (g/100 } \\
\text { g) }\end{array}$ & $\begin{array}{l}\text { Protein } \\
\text { (g/100g) }\end{array}$ & Fat $(g / 100 g)$ & $\begin{array}{c}\text { TDF } \\
(\mathrm{g} / \mathbf{1 0 0 g})\end{array}$ & $\begin{array}{c}\text { Calories } \\
\text { (kcal) }\end{array}$ \\
\hline \multirow{3}{*}{ Control } & 0 & $93.40 \pm 0.58 \mathrm{a}$ & $5.74 \pm 0.04 a$ & $22.97 \pm 0.88 \mathrm{a}$ & $2.76 \pm 0.02 \mathrm{~h}$ & 452.77 \\
\hline & 5 & $93.06 \pm 0.08 \mathrm{a}$ & $5.51 \pm 0.02 \mathrm{a}$ & $21.20 \pm 0.04 b$ & $4.75 \pm 0.42 \mathrm{~g}$ & 438.48 \\
\hline & 10 & $91.69 \pm 0.83 b$ & $5.48 \pm 0.05 \mathrm{a}$ & $21.42 \pm 0.05 b$ & $6.01 \pm 0.42 \mathrm{f}$ & 429.34 \\
\hline \multirow[t]{5}{*}{ G1-OMF } & 15 & $91.39 \pm 0.43 b c$ & $5.36 \pm 0.02 \mathrm{ab}$ & $21.57 \pm 0.02 b$ & $6.92 \pm 0.34 \mathrm{de}$ & 438.72 \\
\hline & 20 & $90.55 \pm 0.27 \mathrm{~cd}$ & $5.05 \pm 0.07 \mathrm{abc}$ & $21.62 \pm 0.06 b$ & $7.64 \pm 0.11 \mathrm{c}$ & 439.05 \\
\hline & 25 & $90.58 \pm 0.30 \mathrm{~cd}$ & $4.63 \pm 0.67 \mathrm{c}$ & $21.74 \pm 0.04 \mathrm{~b}$ & $8.42 \pm 0.37 \mathrm{~b}$ & 424.60 \\
\hline & 5 & $91.85 \pm 0.28 b$ & $5.45 \pm 0.10 \mathrm{a}$ & $21.39 \pm 0.02 b$ & $4.99 \pm 0.30 \mathrm{~g}$ & 427.70 \\
\hline & 10 & $91.57 \pm 0.03 b$ & $5.41 \pm 0.05 \mathrm{ab}$ & $21.47 \pm 0.08 \mathrm{~b}$ & $6.29 \pm 0.39 \mathrm{ef}$ & 411.67 \\
\hline \multirow[t]{5}{*}{ G1-OMFP } & 15 & $90.54 \pm 0.65 \mathrm{~cd}$ & $5.39 \pm 0.01 \mathrm{ab}$ & $21.62 \pm 0.04 \mathrm{~b}$ & $7.17 \pm 0.36 \mathrm{~cd}$ & 412.18 \\
\hline & 20 & $90.62 \pm 0.24 \mathrm{~cd}$ & $5.13 \pm 0.06 \mathrm{abc}$ & $21.62 \pm 0.01 \mathrm{~b}$ & $8.41 \pm 0.22 b$ & 402.55 \\
\hline & 25 & $90.36 \pm 0.05 d$ & $4.69 \pm 0.85 b c$ & $21.72 \pm 0.06 \mathrm{~b}$ & $9.34 \pm 0.13 \mathrm{a}$ & 398.71 \\
\hline & 5 & $90.93 \pm 1.20 \mathrm{~b}$ & $5.60 \pm 0.18 \mathrm{ab}$ & $21.94 \pm 0.05 b c$ & $3.91 \pm 0.011$ & 428.63 \\
\hline & 10 & $89.39 \pm 0.74 b c$ & $5.01 \pm 0.15 \mathrm{abcd}$ & $22.07 \pm 0.04 b c$ & $4.94 \pm 0.10 \mathrm{~g}$ & 416.93 \\
\hline \multirow[t]{5}{*}{ G2-OMF } & 15 & $88.88 \pm 0.20 \mathrm{c}$ & $5.32 \pm 0.13 \mathrm{bcde}$ & $22.19 \pm 0.06 b c$ & $5.89 \pm 0.09 \mathrm{e}$ & 418.53 \\
\hline & 20 & $86.62 \pm 0.46 \mathrm{~d}$ & $5.25 \pm 0.21 \mathrm{cde}$ & $22.21 \pm 0.06 b c$ & $6.84 \pm 0.11 \mathrm{c}$ & 411.93 \\
\hline & 25 & $86.08 \pm 1.25 \mathrm{~d}$ & $5.22 \pm 0.14 \mathrm{de}$ & $22.29 \pm 0.25 b c$ & $7.49 \pm 0.05 b$ & 409.50 \\
\hline & 5 & $91.08 \pm 0.45 b$ & $5.55 \pm 0.21 \mathrm{abc}$ & $21.89 \pm 0.04 \mathrm{c}$ & $4.07 \pm 0.06$ & 423.42 \\
\hline & 10 & $88.95 \pm 1.20 \mathrm{c}$ & $5.42 \pm 0.12 \mathrm{bcde}$ & $22.02 \pm 0.05 b c$ & $5.18 \pm 0.08 \mathrm{f}$ & 406.52 \\
\hline \multirow[t]{3}{*}{ G2-OMFP } & 15 & $86.55 \pm 1.02 \mathrm{~d}$ & $5.30 \pm 0.13 \mathrm{bcde}$ & $22.13 \pm 0.05 b c$ & $6.06 \pm 0.04 d$ & 416.28 \\
\hline & 20 & $86.01 \pm 0.5 \mathrm{~d}$ & $5.24 \pm 0.05 \mathrm{de}$ & $22.37 \pm 0.06 \mathrm{abc}$ & $6.98 \pm 0.04 c$ & 399.30 \\
\hline & 25 & $85.64 \pm 0.32 d$ & $5.14 \pm 0.06 \mathrm{e}$ & $22.51 \pm 0.08 \mathrm{ab}$ & $7.85 \pm 0.10 \mathrm{a}$ & 398.93 \\
\hline
\end{tabular}

*Means with different superscripts in columns indicate significant difference $(P<0.05)$. Data are expressed as means \pm standard deviations. 


\subsection{Chemical Properties of Cookies}

Table 4 shows the chemical composition of cookies made with OMFs and OMFPs. The protein and fat contents of the cookies containing OMFs and OMFPs showed change compared to the control. OF addition reduced protein and fat contents of cookies. However, replacement of wheat flour with oleaster flour increased dietary fiber contents of cookies compared to the control. Increasing OFs addition levels significantly $(P<0.05)$ enhanced the TDF contents of cookies. Therefore, these cookies with OMFs and OMFPs can claim to be a source of dietary fiber. Cookies made with OMFs and OMFPs have lower energy values compared to control. Oleaster flour supplemantation led to a decrease in caloric content of cookies. The TDF and caloric contents in the cookies with OMFs and OMFPs showed a significant change, which is important for the nutritional effects of oleaster flour. Ajila et al. (2008) reported a increase in TDF of biscuits upon addition of mango peel powder. Seker et al. (2010) also reported that TDF content of the cookies supplemented with apricot kernel flour (AKF)increased significantly as the AKF concentration increased.

\subsection{Physical Characteristics and Texture Properties of Cookies}

The diameter and spread ratio of cookies supplemented with varying levels of OMF and OMFP are presented in Table 5. Spread ratio (diameter/thickness) is one of the most important properties in evaluating the quality of cookies. Greater spread ratios are desirable and indicate a better cookie quality (Seker et al., 2010). Spread ratio (SR) values of OFs supplemented cookies increased significantly $(P<0.05)$ in both genotypes $(\mathrm{G} 1, \mathrm{G} 2)$ and in both flour types (OMF, OMFP) at all levels. Control had the lowest SR (3.64) value while the 25\% G1-OMF and G1-OMFP had the highest SR (6.23 and 6.20\%, respectively) values. The SR value, ranging from 3.94 to 6.23 , increased with the increase in the level of OF products. In our study, the substitution of wheat flour with oleaster flour (OF) led to a significant increase in spread ratio.

Table 5. Physical characteristics of cookies*

\begin{tabular}{ccccc}
\hline Sample code & OF Level (\%) & Diameter (cm) & Spread Ratio & Hardness (Peak force) (g) \\
\hline Control & 0 & $5,70 \pm 0,15 \mathrm{c}$ & $3,64 \pm 0,35 \mathrm{c}$ & $39,06 \pm 3,41 \mathrm{de}$ \\
& 5 & $6,60 \pm 0.02 \mathrm{a}$ & $5,14 \pm 0,20 \mathrm{~b}$ & $40,47 \pm 1,36 \mathrm{cde}$ \\
G1-OMF & 10 & $6,54 \pm 0.02 \mathrm{ab}$ & $5,34 \pm 0,18 \mathrm{~b}$ & $42,06 \pm 9,51 \mathrm{bcde}$ \\
& 15 & $6,53 \pm 0,02 \mathrm{ab}$ & $5,60 \pm 0,28 \mathrm{~b}$ & $42,07 \pm 13,27 \mathrm{bcde}$ \\
& 20 & $6,32 \pm 0,07 \mathrm{~b}$ & $6,18 \pm 0,23 \mathrm{a}$ & $45,57 \pm 11,58 \mathrm{bcde}$ \\
& 25 & $6,33 \pm 0.02 \mathrm{~b}$ & $6,23 \pm 0,42 \mathrm{a}$ & $55,30 \pm 11,24 \mathrm{abc}$ \\
G1-OMFP & 5 & $6,64 \pm 0,16 \mathrm{a}$ & $5,25 \pm 0,28 \mathrm{~b}$ & $39,51 \pm 7,02 \mathrm{de}$ \\
& 10 & $6,52 \pm 0,12 \mathrm{ab}$ & $5,48 \pm 0,16 \mathrm{~b}$ & $50,86 \pm 10,25 \mathrm{bcd}$ \\
& 15 & $6,30 \pm 0.01 \mathrm{~b}$ & $5,55 \pm 0,07 \mathrm{~b}$ & $55,72 \pm 12,65 \mathrm{abc}$ \\
& 20 & $6,33 \pm 0,07 \mathrm{~b}$ & $5,65 \pm 0,27 \mathrm{ab}$ & $56,07 \pm 8,43 \mathrm{ab}$ \\
G2-OMF & 25 & $6,34 \pm 0.02 \mathrm{~b}$ & $6,20 \pm 0,72 \mathrm{a}$ & $66,98 \pm 8,33 \mathrm{a}$ \\
& 5 & $5,96 \pm 0,03 \mathrm{~b}$ & $3,94 \pm 0,34 \mathrm{c}$ & $41,18 \pm 14,58 \mathrm{bcd}$ \\
& 10 & $6,01 \pm 0,07 \mathrm{~b}$ & $4,46 \pm 0,17 \mathrm{c}$ & $43,95 \pm 7,73 \mathrm{abc}$ \\
& 20 & $6,16 \pm 0,10 \mathrm{a}$ & $4,78 \pm 0,54 \mathrm{~b}$ & $48,67 \pm 9,69 \mathrm{bc}$ \\
& 25 & $6,17 \pm 0,03 \mathrm{a}$ & $4,80 \pm 0,43 \mathrm{~b}$ & $50,22 \pm 3,52 \mathrm{ab}$ \\
& 5 & $6,28 \pm 0,10 \mathrm{a}$ & $5,53 \pm 0,10 \mathrm{a}$ & $50,92 \pm 5,42 \mathrm{a}$ \\
& 10 & $6,05 \pm 0,01 \mathrm{~b}$ & $4,26 \pm 0,01 \mathrm{c}$ & $39,31 \pm 1,85 \mathrm{bcd}$ \\
& 15 & $6,11 \pm 0,03 \mathrm{~b}$ & $4,56 \pm 0.02 \mathrm{c}$ & $42,54 \pm 4,96 \mathrm{abcd}$ \\
& 20 & $6,27 \pm 0,06 \mathrm{a}$ & $5,08 \pm 0,17 \mathrm{~b}$ & $45,42 \pm 3,87 \mathrm{abc}$ \\
& 25 & $6,27 \pm 0,07 \mathrm{a}$ & $5,15 \pm 0,29 \mathrm{ab}$ & $47,71 \pm 2,74 \mathrm{ab}$ \\
& $6,33 \pm 0,06 \mathrm{a}$ & $5,77 \pm 0,07 \mathrm{a}$ & $52,47 \pm 2,79 \mathrm{a}$ \\
\hline
\end{tabular}

* Means with different superscripts in columns indicate significant difference $(P<0.05)$. Data are expressed as means \pm standard deviations. 
Diameter values of the cookies generally followed a similar trend with the SR values. Cookies with oleaster flours were found to be larger in diameter than control cookies. Control had the lowest diameter $(5.70 \mathrm{~cm})$ while the 5\% G1-OMFP and 5\% G1-OMF had the highest diameter (6.64 and $6.60 \%$, respectively). Cookie diameter was found to be significantly $(P<0.05)$ affected by adding OF samples (Table 5). Cookies of enriched with OMFs and OMPFs showed higher diameter and spread ratio values than the control.

Table 5 shows the hardness of cookies made with different percentages of oleaster flours. Among the G1-OMF supplemented samples, only $25 \%$ supplementation significantly $(P<0.05)$ increased the hardness values of the cookies. Other G1-OMF levels had no significant effect on the hardness values of cookies. Cookies made with all G1-OMFP levels except 5 and $10 \%$ had significantly $(P<0.05)$ higher hardness as compared to control cookie. Cookies prepared from G2-OMF containing except 5\% level had significantly $(P<0.05)$ harder than control. The G2-OMFP levels except 5 and $10 \%$ had significant effect on the hardness values of cookies. In general, hardness tends to increase as the amount of OMFs and OMFPs increased in the cookies. Since oleaster flour (OF) contains dietary fiber, water absorption capacity of dough is high. For this reason, an extensive gluten structure occurs. As a result, doughs provide the harder cookies formation. Similar results were reported by Sudha et al. (2007). These researchers reported that a increase in diameter and in breaking strength of cookies upon addition of oat bran.

Table 6. Colour properties of cookies ${ }^{\dagger}$

\begin{tabular}{ccccc}
\hline \multirow{2}{*}{ Sample code } & $\begin{array}{c}\text { OF Level } \\
(\mathbf{\%})\end{array}$ & \multicolumn{3}{c}{ Colour } \\
\cline { 2 - 5 } Control & 0 & $72.66 \pm 1.22 \mathrm{a}$ & $4.86 \pm 1.13 \mathrm{~h}$ & $30.95 \pm 1.43 \mathrm{ab}$ \\
& 5 & $64.95 \pm 0.87 \mathrm{~b}$ & $7.45 \pm 0.24 \mathrm{~g}$ & $29.69 \pm 0.10 \mathrm{bc}$ \\
& 10 & $58.46 \pm 1.97 \mathrm{c}$ & $10.58 \pm 0.71 \mathrm{f}$ & $31.67 \pm 0.60 \mathrm{a}$ \\
G1-OMF & 15 & $55.37 \pm 1.29 \mathrm{~d}$ & $11.42 \pm 0.78 \mathrm{de}$ & $29.81 \pm 0.13 \mathrm{bc}$ \\
& 20 & $49.96 \pm 1.99 \mathrm{e}$ & $13.15 \pm 0.39 \mathrm{ab}$ & $29.39 \pm 0.95 \mathrm{c}$ \\
& 25 & $44.32 \pm 0.93 \mathrm{f}$ & $13.80 \pm 0.39 \mathrm{a}$ & $26.36 \pm 0.91 \mathrm{e}$ \\
& 5 & $60.02 \pm 1.42 \mathrm{c}$ & $10.31 \pm 0.49 \mathrm{f}$ & $31.02 \pm 0.63 \mathrm{ab}$ \\
G1-OMFP & 10 & $60.20 \pm 0.15 \mathrm{c}$ & $9.80 \pm 0.13 \mathrm{f}$ & $30.41 \pm 0.40 \mathrm{abc}$ \\
& 15 & $52.98 \pm 1.93 \mathrm{~d}$ & $11.65 \pm 0.29 \mathrm{~cd}$ & $29.97 \pm 1.01 \mathrm{bc}$ \\
& 20 & $48.83 \pm 1.90 \mathrm{e}$ & $12.59 \pm 0.56 \mathrm{bc}$ & $27.96 \pm 0.22 \mathrm{~d}$ \\
& 25 & $48.75 \pm 1.57 \mathrm{e}$ & $13.26 \pm 0.33 \mathrm{ab}$ & $29.15 \pm 1.23 \mathrm{~cd}$ \\
G2-OMF & 5 & $61.01 \pm 1.74 \mathrm{~b}$ & $8.75 \pm 0.86 \mathrm{e}$ & $30.10 \pm 0.65 \mathrm{a}$ \\
& 10 & $41.79 \pm 1.70 \mathrm{~d}$ & $11.50 \pm 0.49 \mathrm{bc}$ & $29.19 \pm 0.64 \mathrm{~b}$ \\
& 15 & $50.31 \pm 2.25 \mathrm{~d}$ & $11.97 \pm 0.70 \mathrm{ab}$ & $28.89 \pm 1.12 \mathrm{bc}$ \\
& 20 & $45.43 \pm 1.33 \mathrm{f}$ & $12.10 \pm 0.50 \mathrm{a}$ & $25.44 \pm 0.72 \mathrm{~d}$ \\
& 25 & $40.08 \pm 0.50 \mathrm{~h}$ & $12.46 \pm 0.70 \mathrm{a}$ & $22.86 \pm 0.35 \mathrm{f}$ \\
& 5 & $59.68 \pm 2.34 \mathrm{~b}$ & $9.18 \pm 0.66 \mathrm{e}$ & $30.56 \pm 0.60 \mathrm{a}$ \\
& 10 & $55.20 \pm 2.26 \mathrm{c}$ & $9.91 \pm 0.47 \mathrm{~d}$ & $28.13 \pm 0.62 \mathrm{c}$ \\
& 15 & $51.45 \pm 1.40 \mathrm{~d}$ & $11.35 \pm 0.32 \mathrm{c}$ & $28.66 \pm 0.84 \mathrm{bc}$ \\
& 20 & $47.42 \pm 2.96 \mathrm{e}$ & $11.41 \pm 0.36 \mathrm{bc}$ & $25.59 \pm 1.90 \mathrm{~d}$ \\
& 25 & $41.94 \pm 0.93 \mathrm{~g}$ & $12.48 \pm 0.36 \mathrm{a}$ & $24.03 \pm 0.56 \mathrm{e}$ \\
\hline
\end{tabular}

${ }^{\dagger}$ Means with different superscripts in columns indicate significant difference $(P<0.05)$. Data are expressed as means \pm standard deviations.

$\mathrm{L} *$ :lightness of the sample, $100=$ white, $0=$ black; $a *$ : redness when the values are positive and greenness when the values are negative; $b *$ : yellowness when the values are positive and blueness when the values are negative. 


\subsection{Colour Characteristics}

The colour of the cookies affects the consumers' perception and acceptability of the product. The Colour parameters $L *, a *, b *$ are shown in Table 6 . The addition of OMFs and OMFPs had significant $(P<0.05)$ effects on $L^{*}, a^{*}$, and $b^{*}$ values of cookies.

$L^{*}$ value is a measure of the brightness of cookie surface colour. In general, increasing of OMF and OMFP level in the cookies led to significantly $(P<0.05)$ darker appearance of the cookies than the control as indicated by lower $L *$ values due to the possibility of Maillard reactions. Control cookie had the highest brightness compared to the OMFs and OMFPs enriched cookies.

The differences in redness $(a *)$ and yellowness $(b *)$ values were also statistically significant $(P<0.05)$. Increase in redness was observed as the OMF and OMFP level increased from $0 \%$ to $25 \%$. Cookies with OMFs and OMFPs were redder than the control. The ' $b$ *' value, which indicates the yellowness, significantly $(P<0.05)$ decreased with increase in OMF and OMFP level.

Similar changes in colour values were also observed by other investigators who supplemented wheat flour with sugar beet fiber (Koksel \& Ozboy, 1999; Ozturk et al., 2008), flaxseed flour (Khouryieh \& Aramouni, 2012), brewers' spent grain (Ozturk et al., 2002), wheat bran, rice bran, oat bran, and barley bran (Sudha et al., 2007). Due to the enzymatic browning, brightness $\left(L^{*}\right)$ and yellowness $\left(b^{*}\right)$ of the cookies may be decreased.

Table 7. Sensorial characteristics of cookies*

\begin{tabular}{cccccc}
\hline $\begin{array}{c}\text { Sample } \\
\text { code }\end{array}$ & $\begin{array}{c}\text { OF Level } \\
\mathbf{( \% )}\end{array}$ & Appearance & Taste/Flavor & Mouthfeel & $\begin{array}{c}\text { Overall } \\
\text { Acceptability }\end{array}$ \\
\hline Control & 0 & $7.21 \pm 1.62$ & $7.42 \pm 2.17$ & $7.00 \pm 1.63$ & $7.48 \pm 1.51$ \\
& 5 & $7.97 \pm 1.22$ & $7.34 \pm 1.64$ & $6.37 \pm 1.59$ & $7.33 \pm 1.18$ \\
G1-OMF & 10 & $7.29 \pm 1.95$ & $6.26 \pm 1.88$ & $5.97 \pm 1.96$ & $6.61 \pm 1.73$ \\
& 15 & $6.31 \pm 1.94$ & $6.14 \pm 1.96$ & $5.06 \pm 1.91$ & $5.98 \pm 1.54$ \\
& 20 & $5.86 \pm 2.34$ & $5.69 \pm 2.00$ & $4.89 \pm 1.81$ & $5.82 \pm 1.85$ \\
& 25 & $4.54 \pm 2.62$ & $4.66 \pm 2.76$ & $5.23 \pm 2.26$ & $5.61 \pm 1.95$ \\
G1-OMFP & 5 & $7.80 \pm 1.55$ & $7.34 \pm 1.41$ & $7.74 \pm 1.38$ & $7.29 \pm 1.42$ \\
& 10 & $7.86 \pm 1.40$ & $6.43 \pm 1.91$ & $5.63 \pm 1.73$ & $6.99 \pm 1.81$ \\
& 15 & $6.20 \pm 2.44$ & $6.77 \pm 1.73$ & $6.77 \pm 1.73$ & $6.88 \pm 1.87$ \\
& 20 & $6.71 \pm 2.57$ & $6.14 \pm 2.29$ & $6.60 \pm 2.26$ & $6.76 \pm 2.00$ \\
G2-OMF & 25 & $5.69 \pm 2.78$ & $5.74 \pm 2.28$ & $6.09 \pm 1.63$ & $6.64 \pm 1.99$ \\
& 5 & $7.21 \pm 1.62$ & $6.68 \pm 1.53$ & $6.05 \pm 1.68$ & $7.23 \pm 1.59$ \\
& 10 & $7.84 \pm 1.68$ & $6.58 \pm 2.06$ & $6.68 \pm 1.92$ & $6.75 \pm 1.67$ \\
& 20 & $7.21 \pm 1.32$ & $6.16 \pm 1.80$ & $5.53 \pm 1.61$ & $6.30 \pm 1.66$ \\
& 25 & $6.79 \pm 1.47$ & $5.53 \pm 1.74$ & $4.68 \pm 1.67$ & $5.97 \pm 1.83$ \\
G2-OMFP & 5 & $7.21 \pm 1.88$ & $7.00 \pm 1.89$ & $6.47 \pm 1.47$ & $7.22 \pm 1.57$ \\
& 10 & $7.42 \pm 1.57$ & $7.21 \pm 1.89$ & $5.84 \pm 2.70$ & $6.81 \pm 1.92$ \\
& 15 & $7.74 \pm 1.66$ & $6.58 \pm 2.06$ & $6.58 \pm 1.71$ & $6.72 \pm 2.11$ \\
& 20 & $7.32 \pm 1.38$ & $6.72 \pm 2.06$ & $5.42 \pm 1.57$ & $6.59 \pm 1.97$ \\
& 25 & $6.68 \pm 1.38$ & $5.31 \pm 2.20$ & $5.95 \pm 1.81$ & $6.48 \pm 1.81$ \\
\hline
\end{tabular}

*Means with different superscripts in columns indicate significant difference $(P<0.05)$. Data are expressed as means \pm standard deviations. 9-like extremely, 8-like very much, 7-like moderately, 6-like slightly, 5-neither like or dislike, 4-dislike slightly, 3-dislike moderately, 2-dislike very much, and 1-dislike extremely 


\subsection{Sensory Evaluation}

Sensorial characteristics of cookies are presented in Table 7. Cookies with 5\% G1-OMF received the highest appearance score in all samples containing OF. According to appearance scores, all cookies prepared with OFs, except $25 \%$ G1-OMF, were liked moderately and liked slightly by panelists. Oleaster flour addition increased the darkness. Above 20\% supplementation of OMFs and OMFP in the cookie formulation had dark crumb colour. Increasing addition levels of OFs slightly decreased taste/flavor score. The highest taste/ flavor score also belongs to the cookie with 5\% G1-OMF. According to sensory analysis, overall acceptance of cookies were found the best at control sample. All cookies prepared with OFs were liked moderately and like slightly by panelists. Cookies prepared with OMFs and OMFPs at 5\% substitution levels produced cookies close to the control in overall acceptability, as evaluated by a panel of twenty judges. As a result, the usage of $5 \%$ OFs in cookie formulation gave satisfactory results in terms of acceptability.

\section{Discussion}

In accordance with the results oleaster flour (OF) supplementation to cookie formulation increased dietary fiber contents of cookies compared to the control. One serving of cookies ( $=30 \mathrm{~g}$ ) provided $1.8 \mathrm{~g}$ to $2.8 \mathrm{~g}$ total dietary fiber including 10-25\% OFs, which met the US FDA definition of a 'Good Source' of dietary fiber. The physical properties of the OFs enriched cookies were affected in a positive way by demonstrating a decrease in height, an increase in diameter, a higher spread ratio. Despite the significant differences determined between control and OFs added cookies, our results show that it is possible to use OFs to partially substitute for wheat flour in the production of cookies with acceptable physical characteristics. Increasing of OMF and OMFP levels in the cookies led to significantly darker appearance of the cookies than the control due to the possibility of Maillard reactions. According to sensory analysis, overall acceptance of cookies were found the best at control sample. However, panelists liked all cookies with OFs moderately or slightly. Considering the overall acceptance attributes, it can be say that $5 \%$ level of OMF and OMFP was suitable for cookie production. Thus, oleaster, growing almost everywhere naturally in Turkey, could be utilized for the preparation of cookies and other bakery products due to its floury structure, specific taste and functional properties like dietary fibre. The present study demonstrated that considerable nutritive and functional improvement could be attained by the addition of OFs. Further studies could investigate the antioxidant properties and total phenolics of the OFs cookies.

\section{Acknowledgments}

The authors would like to thank the The Scientific and Technological Research Council of Turkey (TUBITAK) for financially support this research project (Project No: TOVAG 110 O 060).

\section{References}

AACCI. (1999). Approved Methods of American Association of Cereal Chemists International, St. Paul, MN, USA.

Ahmadiani, A., Hosseiny, J., Semnanian, S., Javan, M., Saeedi, F., Kamalinejad, M., ... Saremi, S. (2000). Antinociceptive and anti-inflammatory effects of Elaeagnus angustifolia fruit extract. J. Ethnopharmacol., 72, 287-292. http://dx.doi.org/10.1016/S0378-8741(00)00222-1

Ajila, C. M., Leelavathi, K., \& Prasada Rao, U. J. S. (2008). Improvement of dietary fiber content and antioxidant properties in soft dough biscuits with the incorporation of mango peel powder. Journal of Cereal Science, 48, 319-326. http://dx.doi.org/10.1016/j.jcs.2007.10.001

Aksoy, A., \& Sahin, U. (1999). Elaeagnus angustifolia L. as a biomonitor of heavy metal pollution. Turk. J. Bot., $23,83-87$.

AOAC. (1990). Official Methods of Analysis of Association of Official Analytical Chemists (AOAC), Washington, DC, USA.

Ayaz, F. A., \& Bertoft, E. (2001). Sugar and phenolic acid composition of stored commercial oleaster fruits. J. Food Compos. Anal., 14, 505-511. http://dx.doi.org/10.1006/jfca.2001.1004

Gurbuz, I., Ustun, O., Yesilada, E., Sezik, E., \& Kutsal, O. (2003). Anti-ulcerogenic activity of some plants used $\begin{array}{llllll}\text { as folk remedy in Turkey. J. Ethnopharmacol., } & 88, & \text { 93-97. }\end{array}$ http://dx.doi.org/10.1016/S0378-8741(03)00174-0

Khouryieh, H., \& Aramouni, F. (2012). Physical and sensory characteristics of cookies prepared with flaxseed flour. J Sci Food Agric; 92, 2366-2372. http://dx.doi.org/10.1002/jsfa.5642 
Klich, M. G. (2000). Leaf variations in Elaeagnus angustifolia related to environmental heterogeneity. Environ. Exp. Bot., 44, 171-183. http://dx.doi.org/10.1016/S0098-8472(00)00056-3

Koksel, H, \& Ozboy, O. (1999). Effects of sugarbeet fiber on cookie quality. Zuckerindustrie, 124, 542-544.

Lev, E., \& Amar, Z. (2002). Ethnopharmacological survey of traditional drugs sold in the Kingdom of Jordan. $J$. Ethnopharmacol., 82, 131-145. http://dx.doi.org/10.1016/S0378-8741(02)00182-4

Ozturk, S., Ozboy, O., Cavidoglu, I., \& Koksel, H. (2002). Effects of brewer's spent grain on the quality and

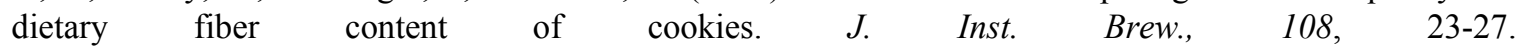
http://dx.doi.org/10.1002/j.2050-0416.2002.tb00116.x

Ozturk, S., Ozboy, O., Javidipour, I., \& Koksel, H. (2008). Utilization of sugarbeet fiber and zero-trans interesterified and non-interesterified shortenings in cookie production. Zuckerindustrie, 133, 704-709

Seker, I. T., Ozbas, O., Gokbulut, I., Ozturk, S., \& Koksel, H. (2010). Utilization of apricot kernel flour as fat replacer in cookies. Journal of Food Processing and Preservation, 34, 15-26. http://dx.doi.org/10.1111/j.1745-4549.2008.00258.x

Sudha, M. L., Vetrimani, R., \& Leelavathi, K. (2007). Influence of fibre from different cereals on the rheological characteristics of wheat flour dough and on biscuit quality (In Press). Food Chemistry, 100, 1365-1370. http://dx.doi.org/10.1016/j.foodchem.2005.12.013 